\title{
New Polysiloxane Surfaces Modified with Ortho-, Meta-, or Para-Nitrophenyl Moieties for Cadmium Removal from Water
}

\author{
Shehdeh Jodeh ${ }^{*}$, Bayan Khalaf1, Smaail Radi², Said Tighadouini'2, Rachid Salghi' ${ }^{3}$, \\ Sobhi Samhan', Ismail Warad1, Diana Jodeh ${ }^{5}$ \\ ${ }^{1}$ Department of Chemistry, An-Najah National University, Nablus, Palestine \\ ${ }^{2}$ Laboratoire de Chimie Appliquée et Environnement, Oujda, Morocco \\ ${ }^{3}$ Laboratory of Materials and Environment, University Ibn Zohr, Agadir, Morocco \\ ${ }^{4}$ Palestine Authority of Water, Ramallah, Palestine \\ ${ }^{5}$ Department of Medicine, An-Najah National University, Nablus, Palestine \\ Email: "sjodeh@hotmail.com
}

Received 15 February 2016; accepted 4 April 2016; published 7 April 2016

Copyright (C) 2016 by authors and Scientific Research Publishing Inc.

This work is licensed under the Creative Commons Attribution International License (CC BY). http://creativecommons.org/licenses/by/4.0/

(c) (i) Open Access

\section{Abstract}

This study aims to prepare and develop several vehicles chelation polydentate supported ligands and then installed it using sol-gel or polymerization or to be susceptible to imply conjunction with the highly toxic heavy metal ions in the water, and disrupted the underground water used for drinking or agriculture, including cadmium ions. As the process of interaction between ligands and heavy metals depends on the circumstances of surrounding conditions which are treated in this research. Metal ion uptake through complexation or hydrogels can be affected by hydrophilichydrophobic balance, the nature of chelate ligands and the extent of cross-linking of macromolecular supports. Ligand function also dictates reactivity, complexation ability and efficiency of polymer supported ligands in the present case expected to be good solution for such problem. This research involves the synthesis and characterization of new polysiloxane surfaces modified with ortho-, meta-, or para-nitrophenyl moieties. The resulting adsorbents have been characterized by SEM, IR, UV, ${ }^{13} \mathrm{C}$ solid state NMR, BET surface area, B.J.H. pore sizes, TGA and nitrogen adsorption-desorption isotherm. These porous materials showed a very good thermal and chemical stability and hence they can be used as perfect adsorbents to uptake toxic heavy metal ions including Cd(II) from groundwater. The concentrations of each adsorbate in the filtrate were determined using Atomic Absorption Spectrophotometer. The results showed that all of the three resulting products had high adsorption efficiency. Also, it showed strong complexation properties with heavy metal ions.

\footnotetext{
${ }^{*}$ Corresponding author.
}

How to cite this paper: Jodeh, S., Khalaf, B., Radi, S., Tighadouini, S., Salghi, R., Samhan, S., Warad, I. and Jodeh, D. (2016) New Polysiloxane Surfaces Modified with Ortho-, Meta-, or Para-Nitrophenyl Moieties for Cadmium Removal from Water. Journal of Surface Engineered Materials and Advanced Technology, 6, 18-35. http://dx.doi.org/10.4236/isemat.2016.62003 


\section{Introduction}

The increasing levels of heavy metal ions in the water resources and environment represent a serious threat to human health, ecological systems and living resources. Although there are many sources of heavy metals in addition to the natural ones, some industrial sectors are at present those which contribute the most to environmental pollution with these toxic elements. Among such industrial sectors the metal finishing industry is an important one, due to the large number of enterprises by which is integrated as well as their geographical dispersion. The main way of contamination of these industries is the emission of liquid effluents with relatively low, although harmful metal concentrations (up to some hundreds of mg/L), mostly, mercury, lead, chromium, cadmium, copper, zinc and nickel.

There are other types of toxicities in addition to the accumulative, such as synergistic toxicity in which the total toxicity of the two toxins is more than the sum of the independent toxicities of them. For example, zinc and cadmium show up five times toxicity more than the sum of their independent toxicities. While in the other type of toxicity, that is antagonistic toxicity; the total toxicity of the two toxins is less than the sum of their independent toxicities, for example, copper and zinc [1] [2].

Many methods, such as reduction and precipitation, ion exchange, reverse osmosis and adsorption, have been proposed to remove heavy metal ions from wastewater [3]-[6]. Among these technologies, many researches concentrated on metal ion recovery using appropriate chelate polymer surfaces, because they are reusable, easy handing and have higher adsorption capacities, efficiencies as well as high selectivity to some metal ions [6]. Hence, numerous chelating resins have been prepared through the polymerization of conventional chelating monomers, such as acrylic acid [7], allylthiourea [8], vinyl pyrrolidone [9], and vinyl imidazole [10]. Additionally modification of a synthetic polymer [11] or a natural polymer matrix [3] by functionlization reactions has also been used to form a chelating polymer. Thus, numerous chelating resins have been successfully prepared via an epoxy group reaction of poly(glycidyl methacrylate) with amines. In addition, glycine is a low-priced amino acid that possesses an amino and a carboxyl group to share electron pairs with a metal ion [5] [11]. In general, heavy metals toxicity depends on a number of factors. These are the total dose absorbed, speciation, the route of exposure and the age of person. For example, young children are more susceptible to the effects of lead exposure because their organs absorb several times the percent ingested compared with adults [12].

Polysiloxanes are one of the most important organosilicon polymers that are used in polymer chemistry. The silanol $\mathrm{SiO}\left(\mathrm{CH}_{3}\right)_{2}$ is the key functional group for the synthesis of these polymers. Silicon ( $\mathrm{Si}$ ) is a semi-metallic element. It makes up $27 \%$ of the earth's crust by mass, and it is the second in abundance in the world (after oxygen). Silicon plays an important role in industry, such as solar energy and computers.

There are many useful properties of polysiloxanes such as, low glass transition temperature, permeability to gases, low surface energy and flexibility.

Adsorption process is usually studied through graph known as adsorption isotherm. That is the amount of the adsorbate on the adsorbent as a function of its pressure (if gas) or concentration (if liquid) at constant temperature.

Analysis of the isotherm data is important to develop an equation, which accurately represents the observed results. The most common isotherms that are applied in solid/liquid systems are the theoretical equilibrium isotherm models, which are Langmuir and Freundlich isotherms [13].

In this work, chelating polysiloxane surfaces derived from carbaldehyde derivatives and 3-aminopropyl trimethoxysilane were synthesized and then functionalized with ortho-,meta- or para-nitrophenyl moieties for the removal of $\mathrm{Cd}(\mathrm{II})$ from an aqueous solution. The effects of solution conditions including $\mathrm{pH}$ value, temperature, contact time, adsorbent dose and metal ion concentration, on the adsorption behaviour were investigated. Also, the adsorption isotherm models, kinetics and thermodynamics parameters were studied.

\section{Experimental Section}

\subsection{Chemical Materials}

All of the chemical substances that are employed in this work were of analytical grade and are used without any 
further purification. The required chemicals involve: silica gel (E. Merck) with particle size in the range of (70 230) mesh, and a median pore diameter of $60 \AA$, was activated for 24 hours before use by heating it at $150^{\circ} \mathrm{C}, 3-$ aminopropyltrimethoxysilane that is purchased from Janssen Chimica, ethanol, toluene, $\mathrm{SnCl}_{2}$, dichloromethane, acetonitrile, dry diethyl ether, $\mathrm{HCl}$ solution, $\mathrm{NaOH}$ solution, $\mathrm{Cd}\left(\mathrm{NO}_{3}\right)_{2} \cdot 4 \mathrm{H}_{2} \mathrm{O}$.

\subsection{Instrumentations}

The required instrumentations for this research include the following: shaking water bath (Daihan Labtech, 20 to 250 rpm Digital Speed Control), pH meter (model: 3510, JENWAY), glassware, thermometer, AAS instrument Thermal Fisher, USA), UV spectrometry, (model: UV-1601, SHIMADZU), IR Spectrometer (Nicolet iS5, iD3 ATR, Thermo Scientific), TGA (Q50 V20.10 Build 36 instrument at a heating rate of $10^{\circ} \mathrm{C} \cdot \mathrm{min}^{-1}$ and in $\mathrm{N}_{2}$ gaseous atmosphere).

\subsection{Preparation of Silica-Immobilized Propylamine ( $\left.\mathrm{SiNH}_{2}\right)$}

There are two common methods used to prepare functionalized polysiloxane ligand systems. The first method called the sol-gel process which involves hydrolysis and condensation of $\mathrm{Si}(\mathrm{Oet})_{4}$ with the appropriate silane coupling agent $(\mathrm{RO})_{3} \mathrm{SiX}$, where; $\mathrm{X}$ represents an organo functionalized ligand. The second method is the chemical modification of the pre-prepared functionalized polysiloxane. This method is used mainly for substitution of organo functionalized groups especially when the appropriate chelating silane agents are difficult to prepare. The most commonly attached chelate ability for this purpose is devoted for donor atoms which have a large capability in forming complexes with a series of heavy metal ions, and in some cases forcing a distinguishable selective extraction property [14].

There are many advantages for using functionalized inorganic supports. For example; lack of swelling in solvents, high hydrolytic, thermal and mechanical stability [15].

This research involves the modification of porous $\mathrm{SiO}_{2}$ with functional ortho-, meta- or para-nitrophenyl receptors using heterogeneous route that involves reaction of carbaldehyde derivatives with 3-aminopropyl trimethoxysilane prior to immobilization on the support [16].

In general, porous silica is usually modified by post-synthesis or one-pot synthesis. In both methods, the organic functional groups are used. The aptitude of the resulting attached chelate is mainly owed to the presence of sulfur, oxygen or nitrogen donor atoms [17].

The first step in the preparation of $\left(\mathrm{SiNH}_{2}\right)$ was the reaction between the silylating agent (3-aminopropyltrimethoxysilane) and the silanol groups on the silica surface. Such that, $25 \mathrm{~g}$ of activated silica gel (SiG) suspended in $150 \mathrm{~mL}$ of toluene was refluxed and mechanically stirred under nitrogen atmosphere for 3 hours. Then, $10 \mathrm{~mL}$ of aminopropyltrimethoxysilane was added dropwise. After that, $1 \mathrm{~g}$ of $\mathrm{SnCl}_{2}$ was used as catalyst and the mixture was kept under reflux for 48 hours.

The resulting solid matrix was filtered, washed with toluene and ethanol, then, it was soxhlet extracted with a (1:1) mixture of ethanol and dichloromethane for $24 \mathrm{~h}$ in order to remove the silylating reagent residue. The obtained immobilized silica gel was dried in vacuum at $20^{\circ} \mathrm{C}$.

\subsection{Synthesis of Nitrophenyl-Substituted Silicas ( $\left.\mathrm{Si}-\mathrm{o}-\mathrm{NO}_{2}\right),\left(\mathrm{Si}-\mathrm{m}-\mathrm{NO}_{2}\right)$ and $\left(\mathrm{Si}-\mathrm{p}-\mathrm{NO}_{2}\right)$}

A mixture of $10 \mathrm{~g}$ of 3-aminopropylsilica $\left(\mathrm{SiNH}_{2}\right)$ with $3 \mathrm{~g}$ of each of ortho-nitroacetophenone, meta-nitroacetophenone or para-nitroacetophenone respectively in $100 \mathrm{~mL}$ of dry diethyl ether was stirred at room temperature for 24 hours. This process results in the formation of the three required adsorbents, including $\left(\mathrm{Si}-\mathrm{o}-\mathrm{NO}_{2}\right)$, $\left(\mathrm{Si}-\mathrm{m}-\mathrm{NO}_{2}\right)$ and $\left(\mathrm{Si}-\mathrm{p}-\mathrm{NO}_{2}\right)$ respectively. After being filtered, the solid products were soxhlet and extracted with acetonitrile, methanol and dichloromethane for 15 hours. Then, these products were dried under vacuum at $70^{\circ} \mathrm{C}$ over 40 hours. The synthesis procedures are shown in Figure 1.

\subsection{Preparation of Standard Solutions}

Cadmium nitrate tetrahydrate $\mathrm{Cd}\left(\mathrm{NO}_{3}\right)_{2} \cdot 4 \mathrm{H}_{2} \mathrm{O}$ with molar mass equals $318.48 \mathrm{~g} \cdot \mathrm{mol}^{-1}$, was used to prepare several standard solutions of $\mathrm{Cd}(\mathrm{II})$ at different initial concentrations depending on dilution calculations.

Such that used solvent for all of these salts was groundwater from Burqin town in Palestine.

The prepared initial concentrations of cadmium ions are: $5,10,15,20,25,30,35,40,45$ and 50 ppm. These 


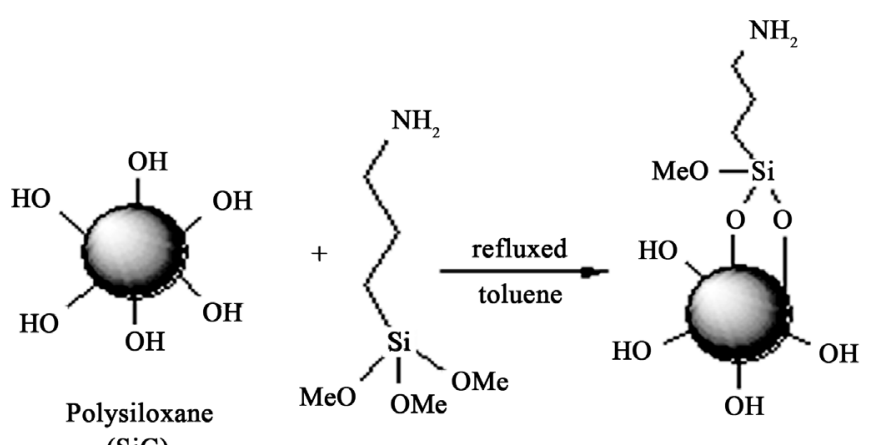

(SiG)

$\mathrm{SiNH}_{2}$

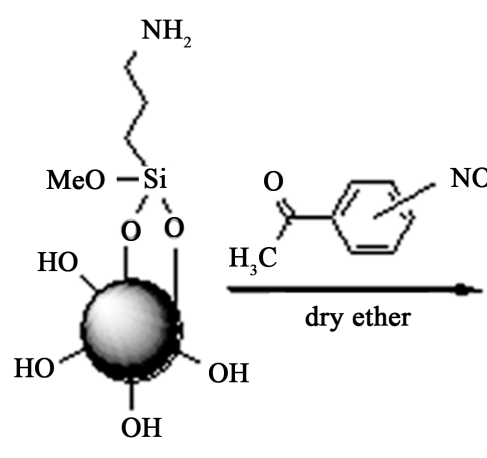

$\mathrm{SiNH}_{2}$<smiles>CC(=N)c1cccc([N+](=O)[O-])c1</smiles>

Figure 1. The synthesis route of modified nitrophenyl-substituted silicas.

standard solutions of calibration are used in batch experiments in order to study the effect of different factors such as; time, $\mathrm{pH}$ and temperature on each adsorption process. And hence to know what are the optimum conditions for having efficient adsorption of $\mathrm{Cd}(\mathrm{II})$ on ortho-, meta-, or para-nitrophenyl silicas.

By using AAS measurements and depending upon the resulting calibration curves, the concentrations of cadmium, lead and nickel ions in the used ground water (without any treatment) equal zero.

\subsection{Batch Experiments}

A mixture of $1 \mathrm{mg}$ sample of $\left(\mathrm{Si}-\mathrm{o}-\mathrm{NO}_{2}\right),\left(\mathrm{Si}-\mathrm{m}-\mathrm{NO}_{2}\right)$ or $\left(\mathrm{Si}-\mathrm{p}-\mathrm{NO}_{2}\right)$ adsorbent with $7 \mathrm{~mL}$ of groundwater containing known concentration of the $\mathrm{Cd}(\mathrm{II})$ toxic metals was shaken.

The effect of solution conditions including; contact time, temperature, $\mathrm{pH}$ value, the amount of modified polymer and the concentration of toxic metal ion was discussed.

Atomic absorption measurements were used for the filtrate mixture of each sample in order to determine the remained amount of the toxic metal ion and hence investigating the extent of the adsorption efficiency.

\subsubsection{Effect of Contact Time}

The adsorption of toxic heavy metals on each adsorbent was studied as a function of shaking time at $20^{\circ} \mathrm{C}$. A sample of $10 \mathrm{ppm}$ of standard solutions at $\mathrm{pH}$ value equals 6 was taken in a volumetric flask and shaken with 1 $\mathrm{mg}$ of an adsorbent. At the end of time intervals (1 minute to 30 hours), each sample was filtered off and the amount of each adsorbate is determined using AAS apparatus.

\subsubsection{Effect of $\mathrm{pH}$}

The effect of $\mathrm{pH}$ value on the adsorption behavior was investigated using different $\mathrm{pH}$ values ranging from 2 to 12. The $\mathrm{pH}$ value was adjusted using roughly concentrations of $0.1 \mathrm{M} \mathrm{HCl}$ and $0.1 \mathrm{M} \mathrm{NaOH}$ solutions.

A $1 \mathrm{mg}$ of an adsorbent sample was added to $7 \mathrm{~mL}$ of the prepared standard solution with a concentration of 
$10 \mathrm{mg} / \mathrm{L}$. The prepared mixtures were placed in shaking water bath at constant temperature $\left(20^{\circ} \mathrm{C}\right)$, with considering into account the resulting optimum time for each previous adsorption process.

\subsubsection{Effect of Temperature}

To study the effect of temperature on each adsorption process, A $1 \mathrm{mg}$ of the adsorbent was added to $7 \mathrm{~mL}$ of the standard solution of Cd(II) with a concentration of $10 \mathrm{ppm}$ at the optimum value of $\mathrm{pH}$.

Each mixture was placed in shaking water bath at desired temperature (the range was $5^{\circ} \mathrm{C}$ to $80^{\circ} \mathrm{C}$ ) for optimum contact time. At the end of time intervals, each sample is filtered off, and the amount of each adsorbate is determined using AAS instrument.

\subsubsection{Effect of Adsorbent Dose}

In order to find out the optimum amount of adsorbent that is required for the adsorption of $\mathrm{Cd}(\mathrm{II})$ on modified silicas, A (1, 2, 3, 4 or $5 \mathrm{mg}$ ) of the modified silica was added to five vials containing $7 \mathrm{~mL}$ of $10 \mathrm{ppm}$ of toxic metal standard solution. The mixtures were placed in shaking water bath at the optimum temperature, $\mathrm{pH}$ and time.

Then, the concentration of each toxic ion in the filtrate is measured using AAS instrument.

\subsubsection{Effect of Adsorbate Concentration}

To find the optimum concentration of cadmium, nickel and lead metal ions. The resulting optimum mass of each adsorbent was added to a number of vials, each contains $7 \mathrm{~mL}$ of different standard concentrations of $\mathrm{Cd}(\mathrm{II})$. Such that all optimum condition of $\mathrm{pH}$, contact time, temperature and the amount of adsorbent must be taken in consideration. After that, the concentration of these toxic ions in each filtrate is measured using AAS apparatus.

\section{Results and Discussion}

\subsection{Materials Characterization}

All materials characterizations like SEM, NMR, UV-Vis, TGA, BET have been studied and published before [16].

\subsection{Adsorption Results}

This research aimed to use the synthesized modified silicas for removing $\mathrm{Cd}(\mathrm{II})$ ions from groundwater, and hence to compare the adsorption efficiency of these polymers. This process is done by studying the adsorption capacities for nitrophenyl substituted silicas towards cadmium adsorbates. The extracted concentrations of cadmium ions were determined using atomic absorption measurements.

After finding the remaining concentrations, the percentage removal for each adsorption process must be determined. This value is defined as the ratio of difference in the adsorbate concentration before and after adsorption $\left(C_{I}-C_{F}\right)$, to the initial concentration of the metal ion in the aqueous solution $\left(C_{I}\right)$, as shown in the following equation:

$$
\% \text { of Removal }=\frac{C_{I}-C_{F}}{C_{I}} \times 100 \%
$$

where,

$C_{I}$ and $C_{F}$ are the initial and finial concentrations of heavy metal ion in groundwater, respectively (ppm).

The adsorption processes are compared according to using the same adsorbent with cadmium, lead or nickel ions or using the same heavy metal with different adsorbents including $\left(\mathrm{Si}-\mathrm{o}-\mathrm{NO}_{2}\right),\left(\mathrm{Si}-\mathrm{m}-\mathrm{NO}_{2}\right)$ or $\left(\mathrm{Si}-\mathrm{p}-\mathrm{NO}_{2}\right)$.

\subsubsection{Adsorption of Cadmium}

The effect of solution conditions for the adsorption of cadmium on $\left(\mathrm{Si}-\mathrm{o}-\mathrm{NO}_{2}\right),\left(\mathrm{Si}-\mathrm{m}-\mathrm{NO}_{2}\right)$ or $\left(\mathrm{Si}-\mathrm{p}-\mathrm{NO}_{2}\right)$ adsorbents is determined. As the adsorbent is changed, the adsorption dependence on the polymer nature is investigated.

1) Effect of Contact Time

In order to establish an appropriate contact time between cadmium ions and each of the adsorbents, adsorption capacities of $\mathrm{Cd}(\mathrm{II})$ were measured as a function of time as shown in Figure 2. 


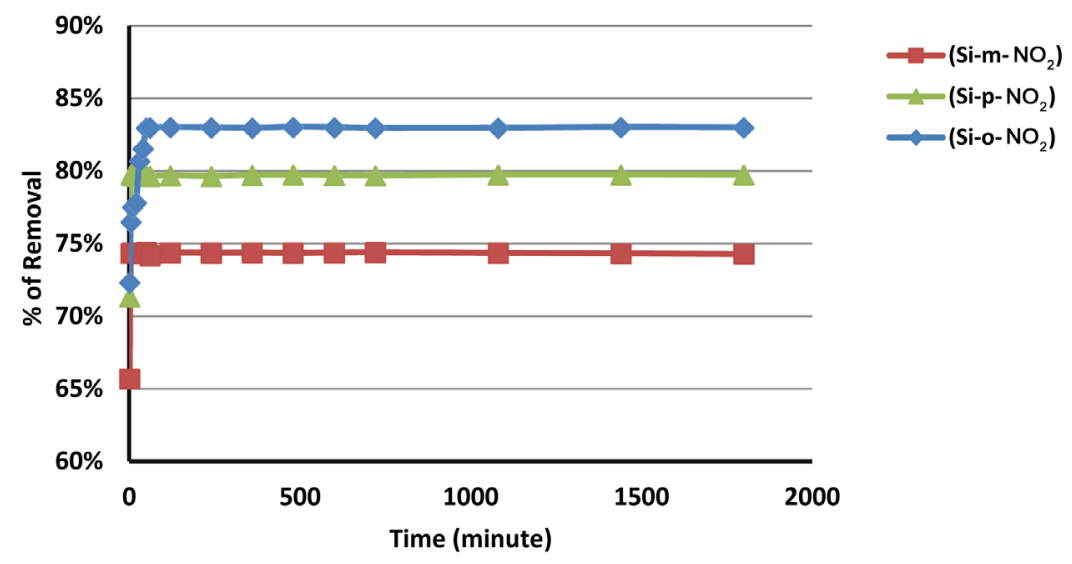

Figure 2. Effect of contact time on the adsorption of $\mathrm{Cd}(\mathrm{II})$ on ortho-, meta- or para-nitrophenyl silicas $\left(\mathrm{C}_{\mathrm{I}}=10 \mathrm{ppm}\right.$, adsorbent dose $=1 \mathrm{mg}$, volume of groundwater $=7 \mathrm{~mL}, \mathrm{pH}=6$, temperature $=20^{\circ} \mathrm{C}$.

This plot shows that the highest percent of $\mathrm{Cd}(\mathrm{II})$ removal was for $\left(\mathrm{Si}-\mathrm{o}-\mathrm{NO}_{2}\right)$ after 50 minutes time of shaking as optimum contact time between the adsorbate and the adsorbent, this percentage is $82.98 \%$. While when $\left(\mathrm{Si}-\mathrm{p}-\mathrm{NO}_{2}\right.$ ) is used for removing cadmium metal ions, the percent of removal is $79.77 \%$ and the optimum contact time is after 5 minutes.

The removal of $\mathrm{Cd}(\mathrm{II})$ from groundwater using $\left(\mathrm{Si}-\mathrm{m}-\mathrm{NO}_{2}\right)$ has a $74.38 \%$ as percent of metal ion removal and optimum contact time of 10 minutes. For the three synthesized adsorbents, the remaining concentration of the cadmium ions after each optimum contact time becomes approximately constant.

The high percentage of Cd(II) removal are due to the high availability of vacant sites on the adsorbent external surface. In general, by considering the large required optimum time (50 minutes) for removing cadmium ions using $\left(\mathrm{Si}-\mathrm{o}-\mathrm{NO}_{2}\right)$ polymer matrix, we can consider that $\left(\mathrm{Si}-\mathrm{p}-\mathrm{NO}_{2}\right)$ is better than $\left(\mathrm{Si}-\mathrm{o}-\mathrm{NO}_{2}\right)$ for $\mathrm{Cd}(\mathrm{II})$ removing, this is because that it requires small optimum time of shaking (only 5 minutes). Also, the difference between these two percentages is also very low $(3.21 \%)$.

2) Effect of $\mathrm{pH}$ Value

$\mathrm{pH}$ value is one of the most important parameters that controlling the uptake of heavy metal ions from aqueous solutions. Figure 3 shows the effect of $\mathrm{pH}$ value on $\mathrm{Cd}(\mathrm{II})$ removal efficiency on different adsorbents. These studies were conducted at the optimum contact times for $\left(\mathrm{Si}-\mathrm{o}-\mathrm{NO}_{2}\right),\left(\mathrm{Si}-\mathrm{m}-\mathrm{NO}_{2}\right)$ and $\left(\mathrm{Si}-\mathrm{p}-\mathrm{NO}_{2}\right)$ adsorbents with varying the $\mathrm{pH}$ value of the solution.

For $\left(\mathrm{Si}-\mathrm{o}-\mathrm{NO}_{2}\right)$ matrix, the percentage adsorption increases with $\mathrm{pH}$ to attain a maximum at $\mathrm{pH} 5$, and thereafter it decreases with further increase in the value of $\mathrm{pH}$. This adsorbent has the maximum percent of $\mathrm{Cd}(\mathrm{II})$ removal that is $84.57 \%$ compared with that for $\left(\mathrm{Si}-\mathrm{p}-\mathrm{NO}_{2}\right)$ that equals $81.72 \%$ and $\left(\mathrm{Si}-\mathrm{m}-\mathrm{NO}_{2}\right)$ that equals $75.39 \%$.

Also, the effect of $\mathrm{pH}$ value on the adsorption efficiency of $\left(\mathrm{Si}-\mathrm{m}-\mathrm{NO}_{2}\right)$ and $\left(\mathrm{Si}-\mathrm{p}-\mathrm{NO}_{2}\right)$ polymers, increases with $\mathrm{pH}$ until reaching a maximum at $\mathrm{pH} 6$ and $\mathrm{pH} 7$ respectively, and thereafter, the percent of cadmium removal decreases with further increase in $\mathrm{pH}$ value.

The increase in metal ion removal as the $\mathrm{pH}$ value increases can be explained on the basis of a decrease in competition between proton and cadmium ions for the same functional groups and by the decrease in the positive surface charge, which results in lower electrostatic repulsion between the surface and metal ions. While, the decreasing behavior of the percentage removal after each optimum $\mathrm{pH}$ for the three synthesized adsorbents is probably due to the formation of a soluble hydroxy complexes which lowers the adsorption efficiency to uptake $\mathrm{Cd}(\mathrm{II})$ from groundwater.

3) Effect of Temperature

To study the effect of temperature on the adsorption of $\mathrm{Cd}(\mathrm{II})$ using ortho-, meta- and para-nitrophenyl silicas. The optimum conditions of contact time and $\mathrm{pH}$ value must be taken in consideration. In general, the adsorption efficiency becomes very low at high temperature values.

As shown in Figure 4, the adsorption of cadmium ions using the three different adsorbents including $\left(\mathrm{Si}-\mathrm{o}-\mathrm{NO}_{2}\right),\left(\mathrm{Si}-\mathrm{m}-\mathrm{NO}_{2}\right)$ and $\left(\mathrm{Si}-\mathrm{p}-\mathrm{NO}_{2}\right)$ has been found to increase with an increase in temperature until reach- 


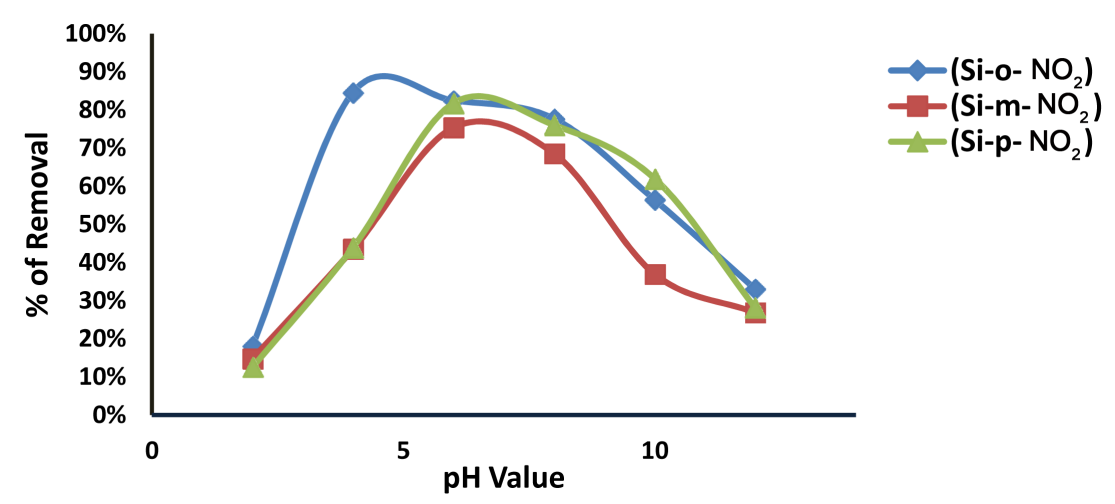

Figure 3. Effect of $\mathrm{pH}$ value on the adsorption of $\mathrm{Cd}(\mathrm{II})$ on ortho-, meta- or para-nitrophenyl silicas $\left(C_{I}=10 \mathrm{ppm}\right.$, adsorbent dose $=1 \mathrm{mg}$, volume of groundwater $=7 \mathrm{~mL}$, temperature $=$ $\left.20^{\circ} \mathrm{C}\right)$.

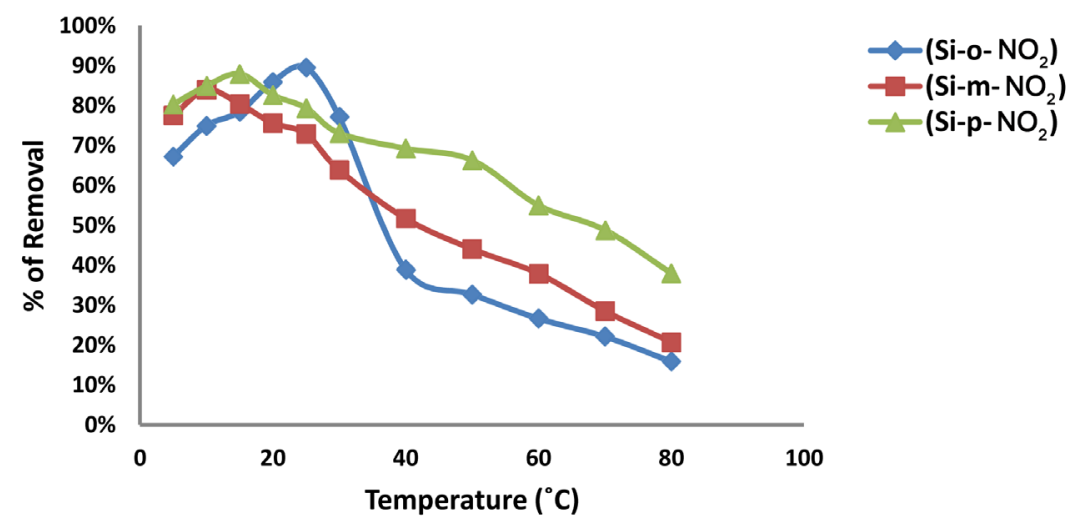

Figure 4. Effect of temperature on the adsorption of $\mathrm{Cd}(\mathrm{II})$ on ortho-, meta- or para-nitrophenyl silicas $\left(C_{I}=10 \mathrm{ppm}\right.$, adsorbent dose $=1 \mathrm{mg}$, volume of groundwater $\left.=7 \mathrm{~mL}\right)$.

ing a maximum at $25^{\circ} \mathrm{C}, 10^{\circ} \mathrm{C}$ and $15^{\circ} \mathrm{C}$ respectively, and thereafter the percentage removal decreases with further heating. Such that the percentages removal at the optimum temperature value are $89.56 \%$ for $\left(\mathrm{Si}-\mathrm{o}-\mathrm{NO}_{2}\right)$, $83.95 \%$ for $\left(\mathrm{Si}-\mathrm{m}-\mathrm{NO}_{2}\right)$ and $87.94 \%$ for $\left(\mathrm{Si}-\mathrm{p}-\mathrm{NO}_{2}\right)$. The low temperature values of the solution enhance the complexation ability between cadmium ions and each of the matrix polymers and hence increase the adsorption efficiency.

4) Effect of Adsorbent Dose

The experimental results for adsorptive removal of cadmium ions with respect to each dose of $\left(\mathrm{Si}-\mathrm{o}-\mathrm{NO}_{2}\right)$, $\left(\mathrm{Si}-\mathrm{m}-\mathrm{NO}_{2}\right)$ and $\left(\mathrm{Si}-\mathrm{p}-\mathrm{NO}_{2}\right)$ adsorbents are shown in Figure 5 over the range of $1 \mathrm{mg}$ to $5 \mathrm{mg}$, at the optimum values of time, $\mathrm{pH}$ and temperature.

The maximum percent of $\mathrm{Cd}$ (II) removal was $98.61 \%$ with using $4 \mathrm{mg}$ of $\left(\mathrm{Si}-\mathrm{m}-\mathrm{NO}_{2}\right)$, such that, this polymer showed an increase in percentage removal with increasing the adsorbent dose. Also, the same relation between adsorption efficiency and dosage effect is observed for $\left(\mathrm{Si}-\mathrm{o}-\mathrm{NO}_{2}\right)$ with $4 \mathrm{mg}$ amount of dose and $95.48 \%$ as percentage removal.

While (Si-p- $\mathrm{NO}_{2}$ ) showed a different effect of adsorbent dose, such that, the maximum observed percent of Cd(II) removal was $89.95 \%$ with only $1 \mathrm{mg}$.

The rapidly increased percentage removal of the metal ion with increase in the dose for ortho- and meta-nitrophenyl receptors is due to the greater availability of the exchangeable sites on the adsorbent surface area. While in the case of $\left(\mathrm{Si}-\mathrm{p}-\mathrm{NO}_{2}\right)$, just only very low amount of this adsorbent showed a very high ability to remove $\mathrm{Cd}(\mathrm{II})$ from groundwater.

5) Effect of Adsorbate Concentration

The effect of the initial concentration of $\mathrm{Cd}(\mathrm{II})$ on the percentage removal of heavy metals using the three prepared adsorbents. Figure 6 indicated that the adsorptive removal decreases with the increase in the initial 


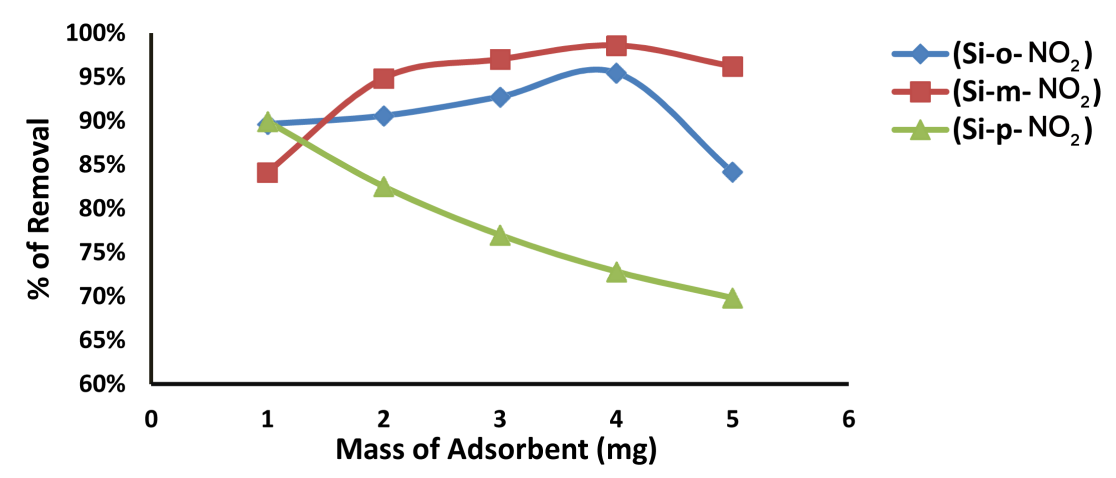

Figure 5. Effect of adsorbent dose on the adsorption of $\mathrm{Cd}(\mathrm{II})$ on ortho-, meta- or para-nitrophenyl silicas $\left(\mathrm{C}_{\mathrm{I}}=10 \mathrm{ppm}\right.$, volume of groundwater $\left.=7 \mathrm{~mL}\right)$.

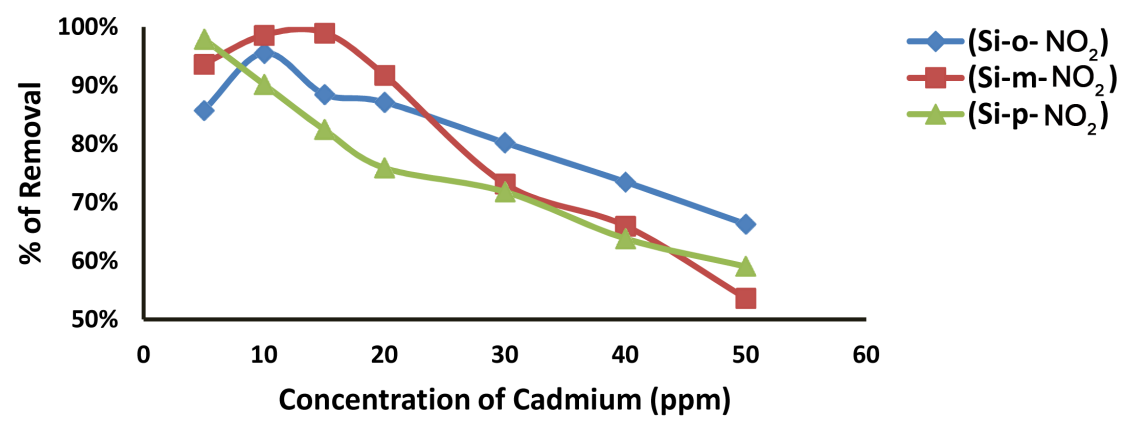

Figure 6. Effect of adsorbate concentration on the adsorption of $\mathrm{Cd}(\mathrm{II})$ on ortho-, meta- or para-nitrophenyl silicas (volume of water $=7 \mathrm{~mL}$ ).

heavy metal concentration. The maximum percent of $\mathrm{Cd}(\mathrm{II})$ removal was $98.99 \%$ for $\left(\mathrm{Si}-\mathrm{m}-\mathrm{NO}_{2}\right)$ by using 15 ppm concentration of cadmium solution. While the observed initial concentrations for having maximum adsorption efficiency for $\left(\mathrm{Si}-\mathrm{o}-\mathrm{NO}_{2}\right)$ and $\left(\mathrm{Si}-\mathrm{p}-\mathrm{NO}_{2}\right)$ polymers are $10 \mathrm{ppm}$ and $5 \mathrm{ppm}$ respectively, with percentage removal of $95.54 \%$ for ortho-nitrophenyl silica and $97.98 \%$ for para-nitrophenyl silica. Generally, lower initial cadmium ion concentrations results in sufficient adsorption sites to be available for adsorption process.

The following table represents the adsorption results for removing cadmium ions from groundwater using $\left(\right.$ Si-o- $\left.\mathrm{NO}_{2}\right),\left(\mathrm{Si}-\mathrm{m}-\mathrm{NO}_{2}\right)$ or $\left(\mathrm{Si}-\mathrm{p}-\mathrm{NO}_{2}\right)$ adsorbents.

\subsection{Investigation of Adsorption Parameters}

In order to investigate the adsorption efficiency for the adsorption of $\mathrm{Cd}(\mathrm{II})$ onto each of the synthesized polymers. The effect of solution conditions on the adsorption process was studied. These conditions involve the effect of shaking time, $\mathrm{pH}$ value, temperature, adsorbent dose and the concentration of adsorbate.

The best equilibrium isotherm model for each adsorption process was investigated according to the value of the correlation coefficient of Langmuir and Freundlich models. The kinetics of adsorption were also investigated using pseudo first-order, pseudo second-order and intra-particle diffusion kinetic models. In addition, Van't Hoff plot for each adsorption process was investigated in order to determine the values of enthalpy change and entropy change, and hence determining if the adsorption is spontaneous $(\Delta S>0)$ or not $(\Delta S<0)$, and if it is exothermic $(\Delta H<0)$ or endothermic one $(\Delta H>0)$.

Finally the effect of adsorbent recovery on the percent of heavy metal ion removal was investigated, and hence the adsorption process with the best regeneration is determined.

\subsubsection{Equilibrium Isotherm Models}

Langmuir isotherm is called the ideal localized monolayer model; it was developed to represent chemisorption. Langmuir isotherm is based on the following assumptions. These are, adsorption is limited to monolayer coverage, such that; the adsorbed molecule cannot migrate across the surface or interact with neighboring molecules. 
Also, the surface of the adsorbent is uniform. This means that all the adsorption sites are equivalent in energy [18].

The Langmuir equation relates the coverage of molecules on a solid surface to the concentration of a medium above the solid surface at a fixed temperature. This equation can be written as:

$$
\frac{C_{e}}{q_{e}}=\frac{1}{b Q_{o}}+\frac{1}{Q_{o}} C_{e}
$$

where,

$C_{e}$ is the equilibrium concentration of the adsorbate $(\mathrm{mg} / \mathrm{L})$;

$b$ is the Langmuir affinity constant $(\mathrm{L} / \mathrm{mg})$;

$Q_{o}$ is the adsorption capacity at equilibrium $(\mathrm{mg} / \mathrm{g})$;

$q_{e}$ is the amount of adsorbate per unit mass of adsorbent $(\mathrm{mg} / \mathrm{g})$, and it can be calculated using the following relation:

$$
q_{e}=\left(C_{o}-C_{e}\right) \frac{V}{m}
$$

where,

$C_{o}$ is the initial concentration of the adsorbate $(\mathrm{mg} / \mathrm{L})$;

$V$ is the volume of the solution (L);

$m$ is the mass of the adsorbent $(\mathrm{g})$;

$\left(C_{o}-C_{e}\right)$ represents the adsorbed amount.

A graph of $\left(C_{e} / q_{e}\right)$ values versus $C_{e}$ is used in order to find the Langmuir parameters (see Figure 7 and Table 1) $[19]$.

Freundlich isotherm was interpreted as adsorption to surfaces supporting sites of varied affinities or to heterogeneous surfaces. Freundlich isotherm assumed that stronger binding sites are occupied first, such that; the binding strength decreases with increasing degree of site occupation.

According to this statement, the adsorbed mass per mass of adsorbent can be expressed by the following equation $[20]$.

$$
\log q_{e}=\log K_{F}+\frac{1}{n} \log C_{e}
$$

where,

$K_{F}$ is the Freundlich constant related to adsorption capacity $(\mathrm{mg} / \mathrm{g})$;

$n$ is the heterogeneity coefficient that gives an indication of how favorable the adsorption process $(\mathrm{g} / \mathrm{L})$.

A plot of $\log q_{e}$ values versus $\log C_{e}$ is used to find Freundlich parameters. Which are, $\log K_{F}$ as y-intercept and $(1 / n)$ as a slope (Figure 8 and Table 1$)$ [21].

In order to determine the best adsorption isotherm for the adsorption of cadmium ions onto ortho-, meta-, or para-nitrophenyl silicas, the observed data were fitted to Langmuir and Freundlich isotherms which describe the relationship between the amounts of $\mathrm{Cd}(\mathrm{II})$ adsorbed and its equilibrium concentration in solution.

The adsorption parameters were investigated by plotting $C_{e} / q_{e}$ versus $C_{e}$ for Langmuir adsorption isotherm and $\log q_{e}$ versus $\log C_{e}$ for Freundlich adsorption isotherm.

\begin{tabular}{|c|c|c|c|c|}
\hline \multirow{4}{*}{ Adsorbents } & \multicolumn{4}{|c|}{ Adsorption of $\mathrm{Cd}(\mathrm{II})$} \\
\hline & \multicolumn{4}{|c|}{ Equilibrium Isotherm Models } \\
\hline & \multicolumn{2}{|c|}{ Langmuir Isotherm } & \multicolumn{2}{|c|}{ Freundlich Isotherm } \\
\hline & $Q_{o}(\mathrm{mg} / \mathrm{g})$ & $b(\mathrm{~L} / \mathrm{mg})$ & $K_{F}(\mathrm{mg} / \mathrm{g})$ & $n(\mathrm{~g} / \mathrm{L})$ \\
\hline $\mathrm{Si}-\mathrm{o}-\mathrm{NO}_{2}$ & 44.247 & -3.228 & 61.475 & -5.734 \\
\hline $\mathrm{Si}-\mathrm{m}-\mathrm{NO}_{2}$ & 39.216 & -4.396 & 55.017 & -7.241 \\
\hline $\mathrm{Si}-\mathrm{p}-\mathrm{NO}_{2}$ & 40.816 & -2.952 & 57.716 & -6.477 \\
\hline
\end{tabular}

Table 1. The parameters of Langmuir and Freundlich isotherms for the adsorption of Cd(II) on $\left(\mathrm{Si}-\mathrm{o}-\mathrm{NO}_{2}\right),\left(\mathrm{Si}-\mathrm{m}-\mathrm{NO}_{2}\right)$ and $\left(\mathrm{Si}-\mathrm{p}-\mathrm{NO}_{2}\right)$. 


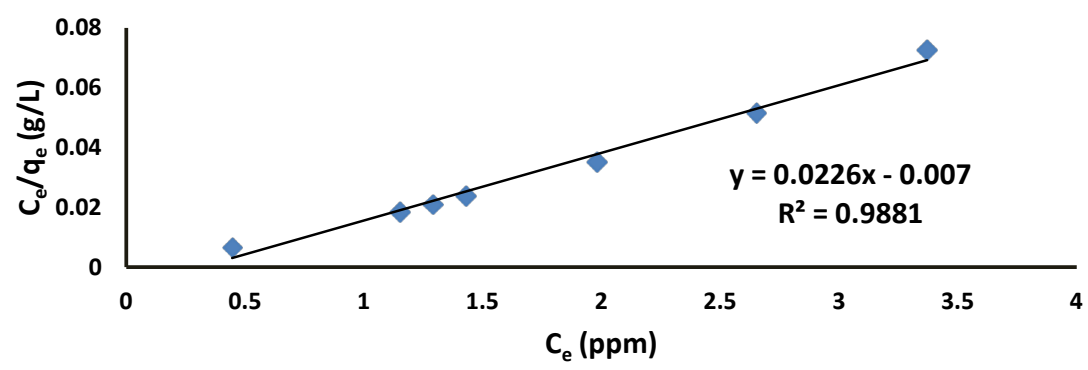

(a)

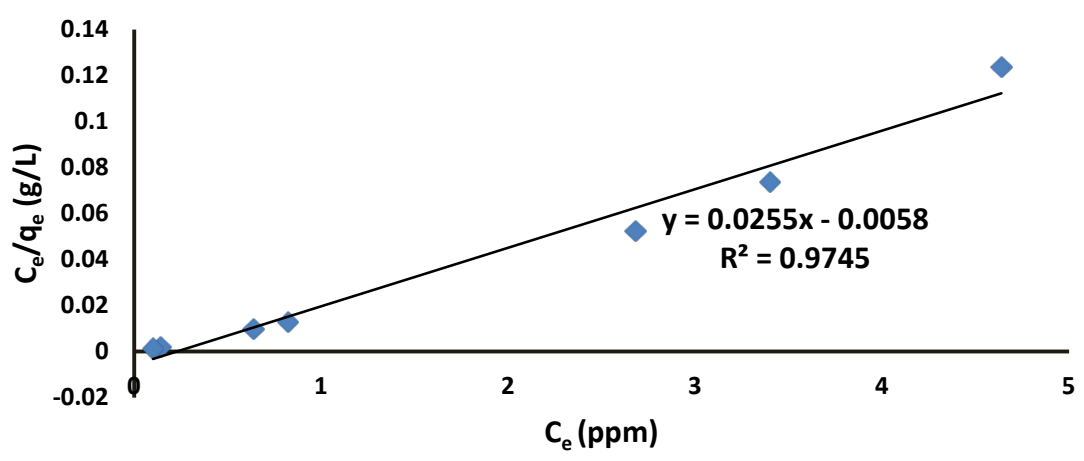

(b)

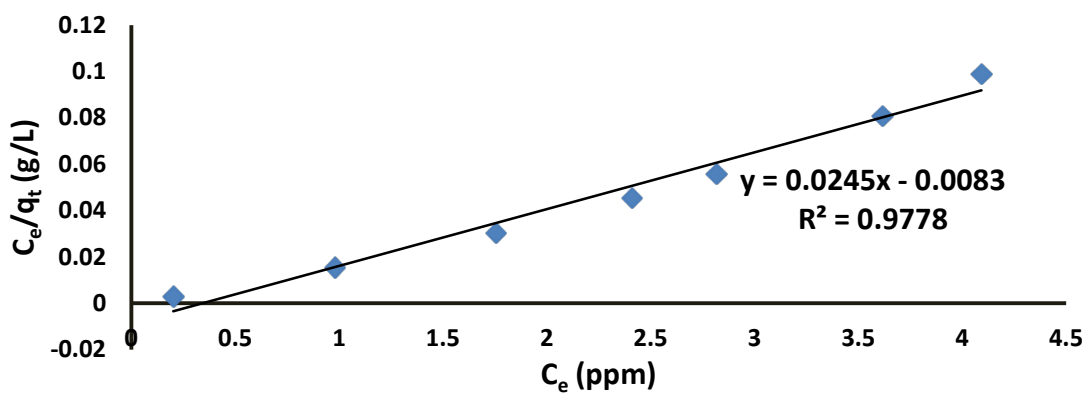

(c)

Figure 7. Langmuir plot for the adsorption of $\mathrm{Cd}(\mathrm{II})$ on a) $\left.\left(\mathrm{Si}-\mathrm{o}-\mathrm{NO}_{2}\right), \mathrm{b}\right)\left(\mathrm{Si}-\mathrm{m}-\mathrm{NO}_{2}\right)$ and c) $\left(\mathrm{Si}-\mathrm{p}-\mathrm{NO}_{2}\right)$; (time $=50$ minute, $\mathrm{pH}=5$, temperature $=25^{\circ} \mathrm{C}$, adsorbent dose $=4 \mathrm{mg}$, volume $=7 \mathrm{~mL}$ ).

1) Langmuir Adsorption Isotherm

As shown from Figure 7 and Figure 8, the values of $\mathrm{R}^{2}$ using Langmuir adsorption isotherm are approximately 1 . This means that the adsorption of $\mathrm{Cd}(\mathrm{II})$ on ortho-, meta, or para-nitrophenyl silicas is chemical adsorption and follows Langmuir equation. Hence this is a strong evidence on the presence of real chemical bonds between the adsorbate and the adsorbent.

From Table 1, Figure 7 and Figure 8, the values of Langmuir and Freundlich isotherm parameters for the adsorption of $\mathrm{Cd}(\mathrm{II})$ on $\left(\mathrm{Si}-\mathrm{o}-\mathrm{NO}_{2}\right),\left(\mathrm{Si}-\mathrm{m}-\mathrm{NO}_{2}\right)$ and $\left(\mathrm{Si}-\mathrm{p}-\mathrm{NO}_{2}\right)$.

2) Adsorption Kinetic Models

The kinetic of adsorption is defined as the process in which adsorbate molecules are transported from bulk solution to a boundary layer of the water surrounding the adsorbent particle by molecular diffusion through the stationary layer of water. Such that the adsorbate particles are transported into an available site. Hence, an adsorption bond will be formed between the adsorbate and the adsorbent [22].

Several adsorption kinetic models have been established in order to describe adsorption kinetics and rate-limiting step. These models give information about the adsorption system behavior and the rate at which specific constituent is removed using a certain adsorbent. In addition, they determine whether the adsorption process is a chemical or a physical one, and which specifically the rate determining step is.

Examples of the adsorption kinetic models include, external mass transfer model, pseudo first-order and 


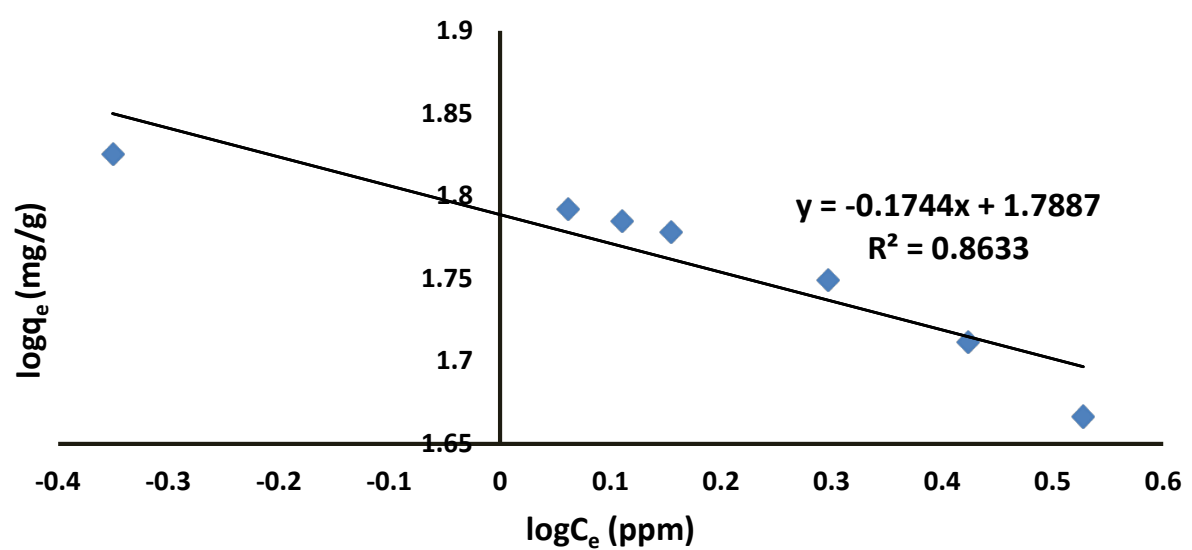

(a)

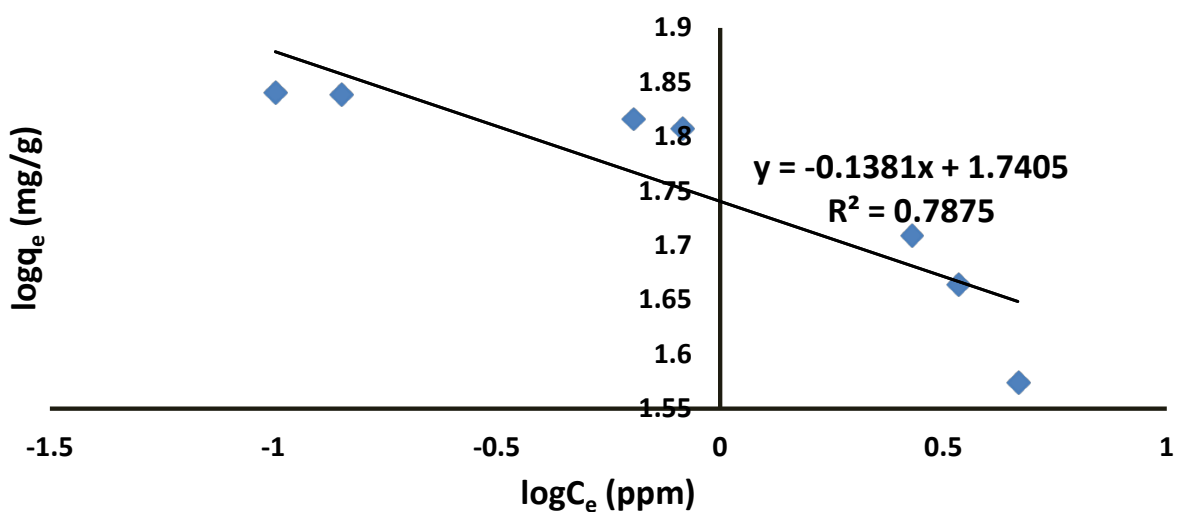

(b)

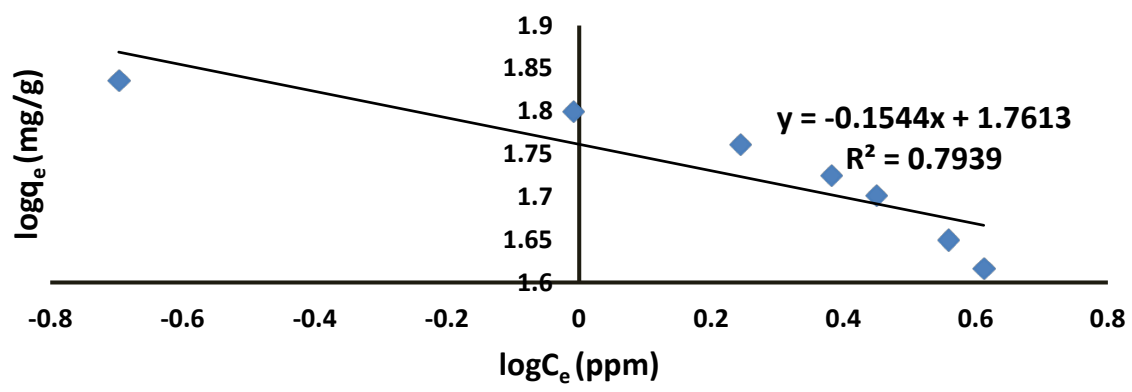

(c)

Figure 8. Freundlich plot for the adsorption of $\mathrm{Cd}(\mathrm{II})$ on (a) $\left(\mathrm{Si}-\mathrm{o}-\mathrm{NO}_{2}\right)$; (b) $\left(\mathrm{Si}-\mathrm{m}-\mathrm{NO}_{2}\right)$ and (c) $\left(\mathrm{Si}-\mathrm{p}-\mathrm{NO}_{2}\right)$. (time $=50$ minute, $\mathrm{pH}=5$, temperature $=25^{\circ} \mathrm{C}$, adsorbent dose $=4 \mathrm{mg}$, volume $\left.=7 \mathrm{~mL}\right)$.

pseudo second-order rate models, Adam-Bohart-Thomas relation, Weber and Morris sorption kinetics, first order reversible reaction model, first-order equation of Bhattacharya and Venkobachar and Elovich's model [23] [24].

a) Pseudo First-Order Kinetics

This kinetic model is considered as the earliest model developed for describing adsorption kinetics. The final integrated equation for this model can be written as:

$$
\log \left(q_{e}-q_{t}\right)=\log q_{e}-\frac{K_{1}}{2.303} t
$$

where,

$q_{e}$ and $q_{t}$ are the masses of adsorbate per unit mass of adsorbent at equilibrium, and at time $t$ respectively 
$(\mathrm{mg} / \mathrm{g})$;

$k_{1}$ is the rate constant of pseudo first-order adsorption model $\left(\mathrm{mg} \cdot \mathrm{g}^{-1} \cdot \mathrm{min}^{-1}\right)$.

A plot of $\log \left(q_{e}-q_{t}\right)$ versus $t$ will give a straight line for the pseudo first-order adsorption with $\log q_{e}$ as $\mathrm{y}$-intercept and $\left(-k_{1} / 2.303\right)$ as the slope of the graph (Figure 9) [25].

b) Pseudo Second-Order Kinetics

This model of kinetics depends on the assumption that the rate-determining step may be chemical adsorption involving valence forces through sharing or exchange of electrons between the adsorbate and the adsorbent.

The rate equation for pseudo second-order kinetic model can be written as:

$$
\frac{t}{q_{t}}=\frac{1}{k_{2} q_{e}^{2}}+\frac{1}{q_{e}} t
$$

where $k_{2}$ is the equilibrium rate constant of pseudo second-order adsorption $\left(\mathrm{g} \cdot \mathrm{mg}^{-1} \cdot \mathrm{min}^{-1}\right)$.

The plot of $t / q_{t}$ versus $t$ should give a linear relationship that allows the computation of a second-order rate constants, $k_{2}$ and $q_{e}$ (Figure 10) [26].

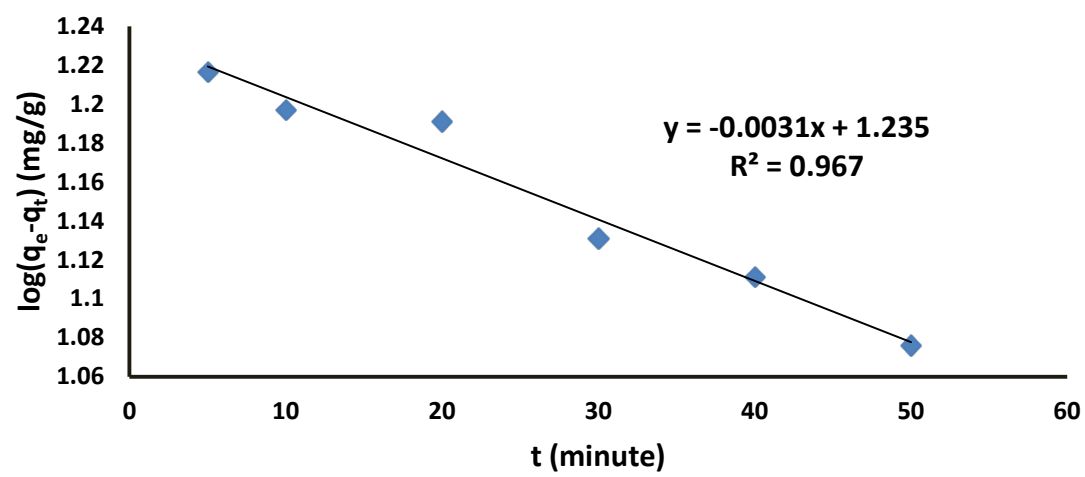

(a)

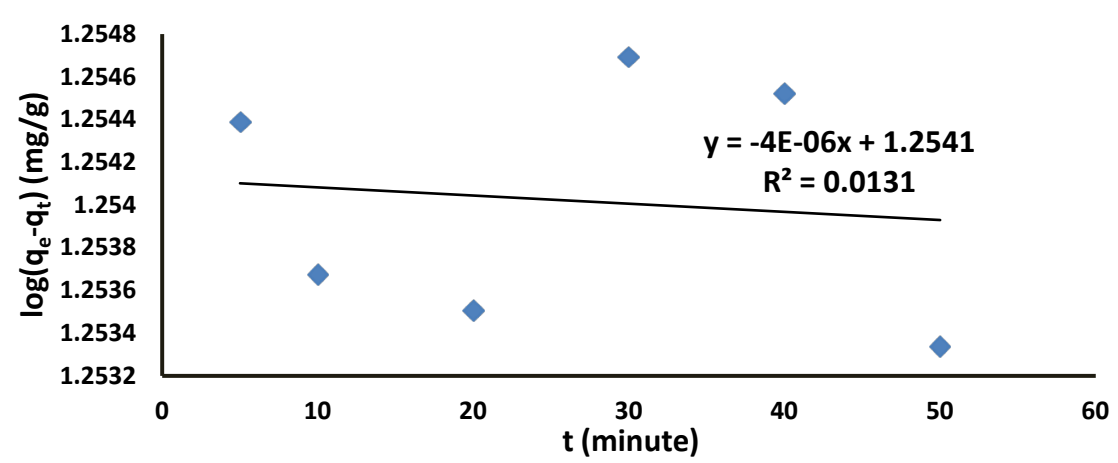

(b)

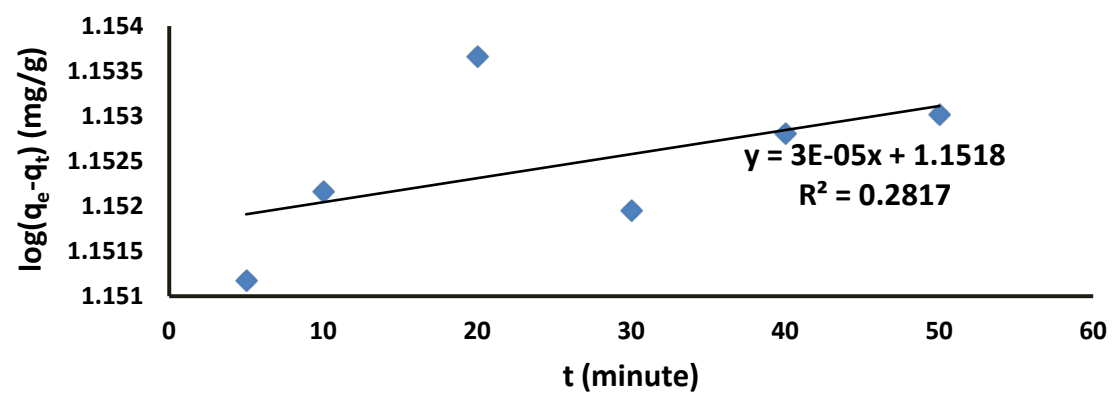

(c)

Figure 9. Pseudo first-order kinetic model for the adsorption of $\mathrm{Cd}(\mathrm{II})$ on $\left(\mathrm{Si}-\mathrm{o}-\mathrm{NO}_{2}\right) \cdot\left(C_{I}=10 \mathrm{ppm}\right.$, $\mathrm{pH}=6$, temperature $=20^{\circ} \mathrm{C}$, adsorbent dose $=1 \mathrm{mg}$, volume $=7 \mathrm{~mL}$ ). 


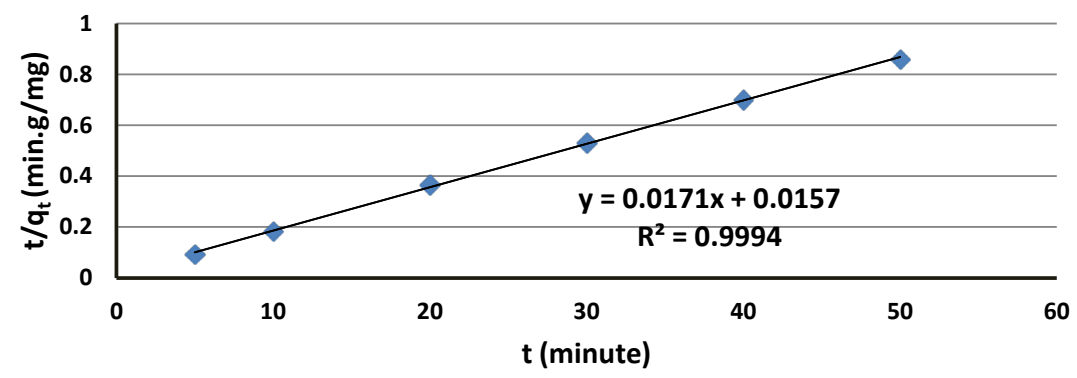

(a)

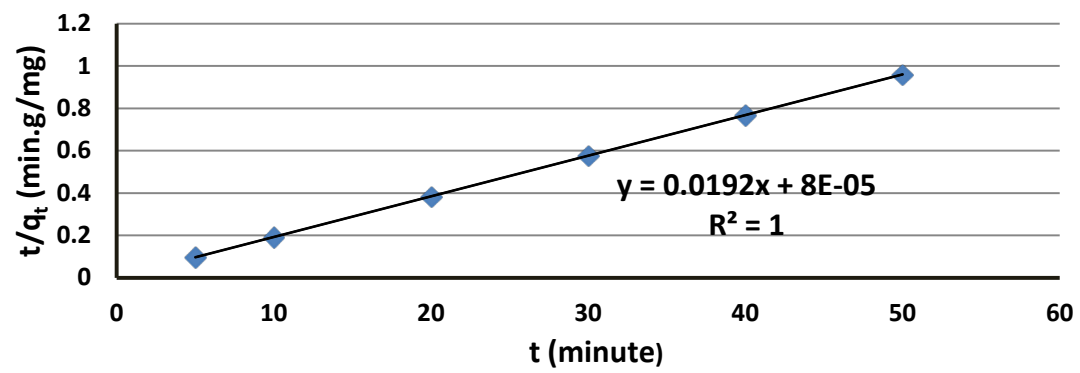

(b)

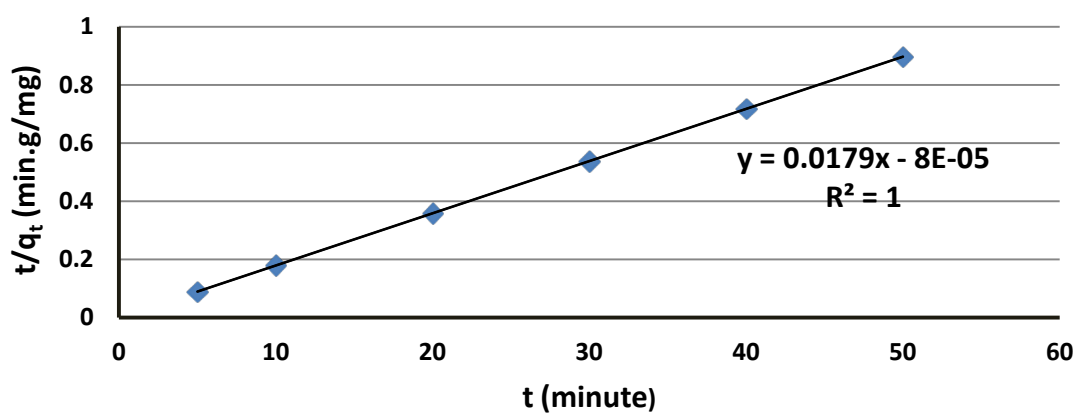

(c)

Figure 10. Pseudo second-order kinetic model for the adsorption of $\mathrm{Cd}(\mathrm{II})$ on $\left(\mathrm{Si}-\mathrm{o}-\mathrm{NO}_{2}\right) \cdot\left(C_{I}=10\right.$ ppm, $\mathrm{pH}=6$, temperature $=20^{\circ} \mathrm{C}$, adsorbent dose $=1 \mathrm{mg}$, volume $=7 \mathrm{~mL}$ ).

c) Intra-Particle Diffusion Kinetic Model

This model is based on the theory proposed by Weber and Morris. The final equation of this adsorption kinetic model is:

$$
q_{t}=K_{p} t^{0.5}+C
$$

where,

$K_{p}$ is the diffusion rate constant $\left(\mathrm{mg} / \mathrm{g} \cdot \mathrm{min}^{1 / 2}\right)$;

$C$ is a constant that gives an indication of the thickness of the boundary layer $(\mathrm{mg} / \mathrm{g})[27]$.

$A$ plot of $q_{t}$ versus $t^{0.5}$ should give a linear relationship for intra-particle diffusion kinetic model with constant $\mathrm{C}$ as a y-intercept and $K_{p}$ as a slope (Figure 11 ).

The experimental kinetics data for $\mathrm{Cd}(\mathrm{II})$ adsorption on the prepared polymers are fitted with pseudo first-order, pseudo second-order and intra-particle diffusion kinetic models in order to investigate the mechanism of each adsorption process.

The kinetics parameters and correlation coefficients have been calculated from the linear plots of $\log \left(q_{e}-q_{t}\right)$ versus $t$ for pseudo first order model, and $t / q_{t}$ versus $t$ for pseudo second-order model and $q_{t}$ versus t for intraparticle diffusion kinetic model, as shown in the following Figures 9-11 and Table 2.

According to the values for the correlation coefficient using the previous kinetic models, it is showed the adsorption of $\mathrm{Cd}(\mathrm{II})$ on $\left(\mathrm{Si}-\mathrm{o}-\mathrm{NO}_{2}\right),\left(\mathrm{Si}-\mathrm{m}-\mathrm{NO}_{2}\right)$ or $\left(\mathrm{Si}-\mathrm{p}-\mathrm{NO}_{2}\right)$ followed the mechanism of pseudo second-order 


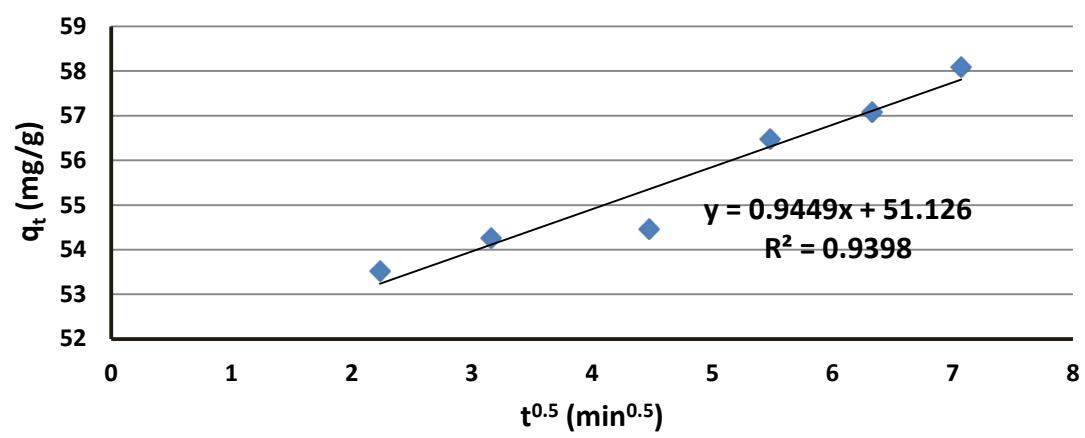

(a)

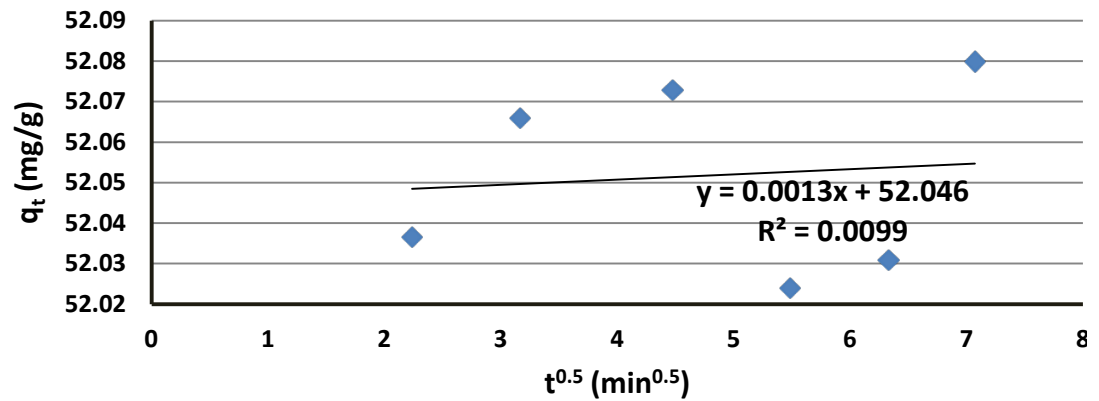

(b)

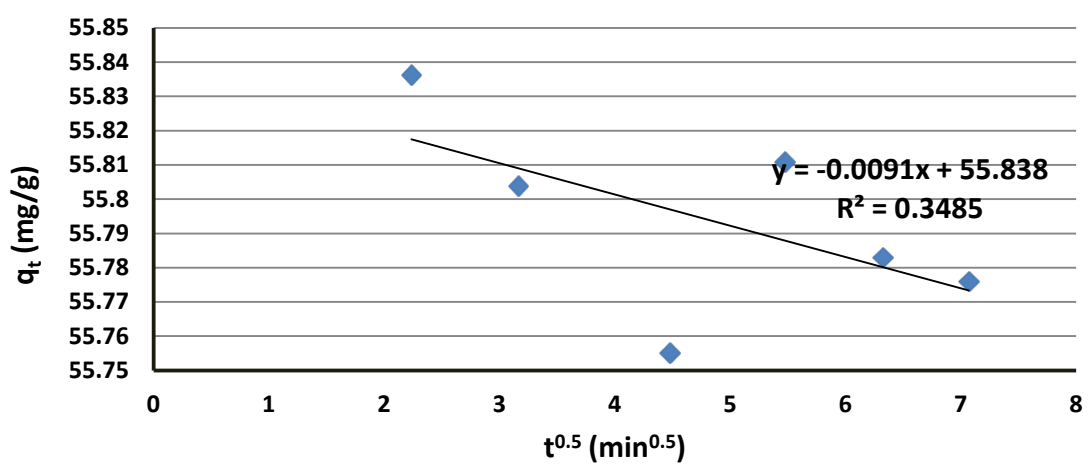

(c)

Figure 11. Intra-particle diffusion kinetic model for the adsorption of $\mathrm{Cd}(\mathrm{II})$ on a) $\left.\left(\mathrm{Si}-\mathrm{o}-\mathrm{NO}_{2}\right), \mathrm{b}\right)\left(\mathrm{Si}-\mathrm{m}-\mathrm{NO}_{2}\right)$ c) $\left(\mathrm{Si}-\mathrm{p}-\mathrm{NO}_{2}\right)\left(\mathrm{C}_{\mathrm{I}}=10 \mathrm{ppm}, \mathrm{pH}=6\right.$, temperature $=20^{\circ} \mathrm{C}$, adsorbent dose $=1 \mathrm{mg}$, volume $\left.=7 \mathrm{~mL}\right)$.

Table 2. The parameters of pseudo first-order, pseudo second-order and intra-particle diffusion kinetic models for the adsorption of $\mathrm{Cd}(\mathrm{II})$ on $\left(\mathrm{Si}-\mathrm{o}-\mathrm{NO}_{2}\right),\left(\mathrm{Si}-\mathrm{m}-\mathrm{NO}_{2}\right)$ and $\left(\mathrm{Si}-\mathrm{p}-\mathrm{NO}_{2}\right)$.

\begin{tabular}{|c|c|c|c|c|c|c|}
\hline \multirow{4}{*}{ Adsorbents } & \multicolumn{6}{|c|}{ Adsorption of Cd(II) } \\
\hline & \multicolumn{6}{|c|}{ Adsorption Kinetic Models } \\
\hline & \multicolumn{2}{|c|}{ Pseudo First-Order Kinetics } & \multicolumn{2}{|c|}{ Pseudo Second-Order Kinetics } & \multicolumn{2}{|c|}{ Intra-Particle Diffusion Kinetics } \\
\hline & $\begin{array}{c}q_{e} \\
(\mathrm{mg} / \mathrm{g})\end{array}$ & $\begin{array}{c}K_{1} \\
\left(\mathrm{mg} \cdot \mathrm{g}^{-1} \cdot \min ^{-1}\right)\end{array}$ & $\begin{array}{c}q_{e} \\
(\mathrm{mg} / \mathrm{g})\end{array}$ & $\begin{array}{c}K_{2} \\
\left(\mathrm{~g} \cdot \mathrm{mg}^{-1} \cdot \min ^{-1}\right)\end{array}$ & $\begin{array}{c}C \\
(\mathrm{mg} / \mathrm{g})\end{array}$ & $\begin{array}{c}K_{p} \\
\left(\mathrm{mg} \cdot \mathrm{g}^{-1} \cdot \min ^{-0.5}\right)\end{array}$ \\
\hline Si-o- $\mathrm{NO}_{2}$ & 17.179 & $7.149 * 10^{-3}$ & 58.479 & 0.0186 & 51.126 & 0.945 \\
\hline $\mathrm{Si}-\mathrm{m}-\mathrm{NO}_{2}$ & 17.952 & - & 52.083 & - & 52.046 & 0.0013 \\
\hline Si-p- $\mathrm{NO}_{2}$ & 14.184 & - & 55.866 & - & 55.838 & 0.0091 \\
\hline
\end{tabular}


kinetic model, and such that, the values of $\mathrm{R}^{2}$ in this kinetic model are approximately one.

Table 2 shows the kinetic parameters of pseudo first-order, pseudo second-order and intra-particle diffusion kinetic models for the adsorption of Cd(II) on ( $\left.\mathrm{Si}-\mathrm{o}-\mathrm{NO}_{2}\right),\left(\mathrm{Si}-\mathrm{m}-\mathrm{NO}_{2}\right)$ and $\left(\mathrm{Si}-\mathrm{p}-\mathrm{NO}_{2}\right)$.

Comparing the value of $q_{e}$ (experimentally) for all adsorption processes that equal 70 , with the values of $q_{e}$ (calculated) in pseudo first-order and pseudo second-order kinetic adsorption models, we conclude that the experimental values for all adsorptions are closer to the values of $q_{e}$ (calculated) in pseudo second-order adsorption model, hence proving that this model represents the mechanism of the adsorption.

3) Adsorption Thermodynamics

Thermodynamic considerations of an adsorption process are necessary to determine whether this process is favorable or not.

This adsorption behavior can be expressed using the thermodynamic parameters including the change in Gibbs free energy $(\Delta G)$, enthalpy change $(\Delta H)$ and the change in entropy $(\Delta S)$;

where $\Delta G$ and $\Delta H$ are in $(\mathrm{J})$ and the unit of $\Delta S$ is $(\mathrm{J} / \mathrm{K})$.

The following equation is the general equation that can be used to relate between the adsorption parameters [28].

$$
\Delta G=\Delta H-T \Delta S
$$

where $T$ is the absolute temperature $(\mathrm{K})$.

The change in Gibbs free energy can be also calculated by the following equation:

$$
\Delta G=-R T \cdot \ln K_{d}
$$

where,

$R$ is the universal gas constant that equals $8.314 \mathrm{~J} \cdot \mathrm{mol}^{-1} \cdot \mathrm{K}^{-1}$;

$K_{d}$ is the thermodynamic equilibrium constant that equals $\left(q_{e} / C_{e}\right)$ with a unit equals (mol) or $(\mathrm{L} / \mathrm{g})$.

The combination of the last two equations will result in the following equation:

$$
\ln K_{d}=\frac{\Delta S}{R}-\frac{\Delta H}{R T}
$$

The plot of $\ln K_{d}$ versus $(1 / T)$ will give a straight line with $(\Delta H / R)$ as slope and $(\Delta S / R)$ as y-intercept. The resulting graph is known as Van't Hoff plot (Figure 12).

By using the thermodynamic equation of Van't Hoff plot, the thermodynamic parameters $(\Delta H$ and $\Delta S)$ for the adsorption of cadmium ions on $\left(\mathrm{Si}-\mathrm{o}-\mathrm{NO}_{2}\right),\left(\mathrm{Si}-\mathrm{m}-\mathrm{NO}_{2}\right)$ or $\left(\mathrm{Si}-\mathrm{p}-\mathrm{NO}_{2}\right)$ can be calculated from the slope and intercepts of the graph of $\ln K_{d}$ versus $(1 / T)$, as shown in Figure 12.

Table 3 represents the values of the thermodynamic parameters ( $\Delta S$ and $\Delta H$ ) for the adsorption of Cd(II) on ortho-, meta-, or para-nitrophenyl silicas.

As shown in this table, the adsorption of $\mathrm{Cd}(\mathrm{II})$ on $\left(\mathrm{Si}-\mathrm{o}-\mathrm{NO}_{2}\right),\left(\mathrm{Si}-\mathrm{m}-\mathrm{NO}_{2}\right)$ or $\left(\mathrm{Si}-\mathrm{p}-\mathrm{NO}_{2}\right)$ adsorbents is endothermic process $(\Delta H>0)$ and non spontaneous $(\Delta S<0)$.

\section{Conclusions}

The synthesis and characterization of the new polysiloxane modified surfaces including $\left(\mathrm{Si}-\mathrm{o}-\mathrm{NO}_{2}\right),\left(\mathrm{Si}-\mathrm{m}-\mathrm{NO}_{2}\right)$ and $\left(\mathrm{Si}-\mathrm{p}-\mathrm{NO}_{2}\right)$ showed that these polymers had very good thermal and chemical stabilities, and hence they can be used as perfect adsorbents to uptake $\mathrm{Cd}(\mathrm{II})$ from groundwater.

Table 3. The thermodynamic parameters for the adsorption of $\mathrm{Cd}(\mathrm{II})$ on $\left(\mathrm{Si}-\mathrm{o}-\mathrm{NO} \mathrm{O}_{2}\right),\left(\mathrm{Si}-\mathrm{m}-\mathrm{NO}_{2}\right)$ and $\left(\mathrm{Si}-\mathrm{p}-\mathrm{NO}_{2}\right)$.

\begin{tabular}{ccc} 
& \multicolumn{2}{c}{ Adsorption of Cd(II) } \\
Adsorbents & \multicolumn{2}{c}{ Adsorption Thermodynamics } \\
\cline { 2 - 3 } & $\Delta H(\mathrm{~kJ})$ & $\Delta S(\mathrm{~J} / \mathrm{K})$ \\
\hline $\mathrm{Si}-\mathrm{o}-\mathrm{NO}_{2}$ & 36.861 & -101.032 \\
$\mathrm{Si}-\mathrm{m}-\mathrm{NO}_{2}$ & 32.148 & -85.052 \\
$\mathrm{Si}-\mathrm{p}-\mathrm{NO}_{2}$ & 24.065 & -54.221 \\
\hline
\end{tabular}




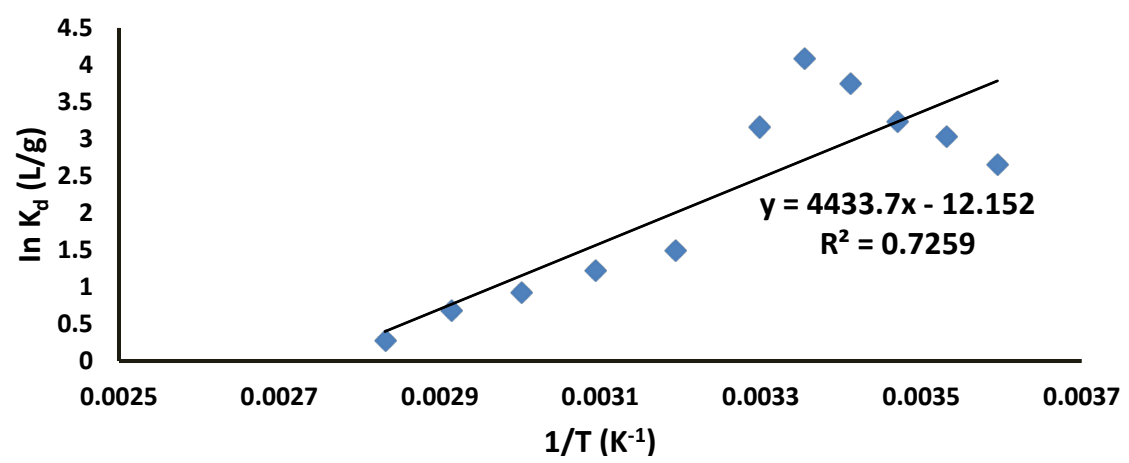

(a)

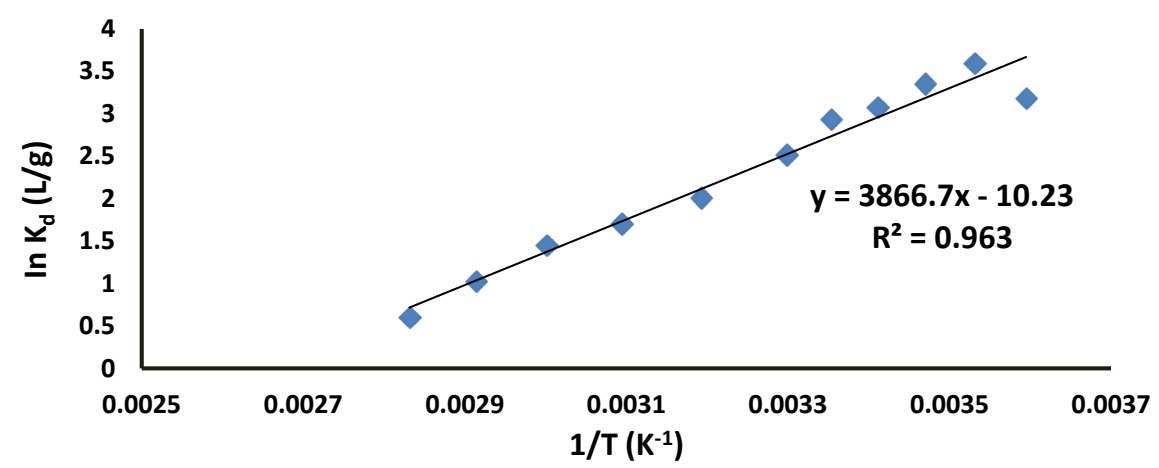

(b)

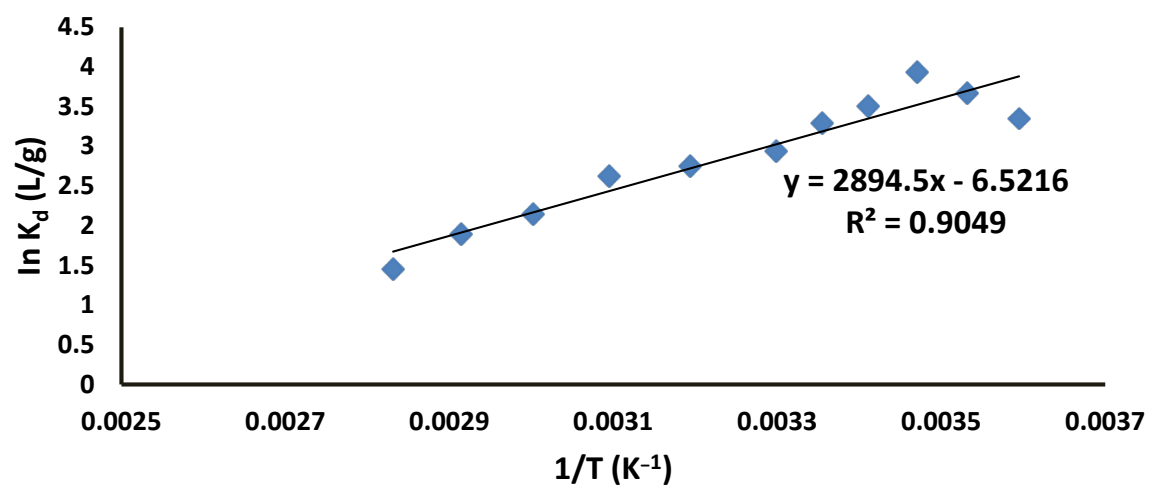

(c)

Figure 12. Van't Hoff plot for the adsorption of $\mathrm{Cd}(\mathrm{II})$ on $\left(\mathrm{Si}-\mathrm{o}-\mathrm{NO}_{2}\right)$. (time $=50$ minute, $C_{I}=10 \mathrm{ppm}$, $\mathrm{pH}=5$, adsorbent dose $=1 \mathrm{mg}$, volume $=7 \mathrm{~mL}$ ).

The observed results of this research include the following.

The results showed that all adsorptions followed Langmuir adsorption isotherm depending on the value of $\mathrm{R}^{2}$ and the mechanism of all adsorption reactions followed pseudo second-order kinetic adsorption model with correlation coefficient of approximately one. Also, the thermodynamic parameters of all the adsorptions proved that these processes were endothermic $(\Delta H>0)$ and non-spontaneous $(\Delta S<0)$.

Finally, the regenerated polymers showed good percentage removal for $\mathrm{Cd}(\mathrm{II})$ and the synthesized adsorbents had high adsorption efficiency and showed a perfect strong complexation property with heavy metal ions.

\section{Acknowledgements}

The authors would like to thank MENA NWC for their financial support for grant No. WIF04. Also, we would extend our thanks to Palestine Water Authority (PWA) and MEDRIC for their financial support for Ms. Bayan Khalaf for paying her tuition while she was student. 


\section{References}

[1] Ngah, W.S.W. and Hanafiah, M. (2008) Removal of Heavy Metal Ions from Wastewater by Chemically Modified Plant Wastes as Adsorbents: A Review. Bioresource Technology, 99, 3935-3948. http://dx.doi.org/10.1016/j.biortech.2007.06.011

[2] Fiol, N., Villaescusa, I., Martinez, M., Miralles, N., Poch, J. and Serarols, J. (2006) Sorption of Pb(II), Ni(II), Cu(II) and Cd(II) from Aqueous Solution by Olive Stone Waste. Separation and Purification Technology, 50, 132-140. http://dx.doi.org/10.1016/j.seppur.2005.11.016

[3] Shukla, S.R., Pai, R.S. and Shendarkar, A.D. (2006) Adsorption of Ni(II), Zn(II) and Fe(II) on Modified Coir Fibres. Separation and Purification Technology, 47, 141-147. http://dx.doi.org/10.1016/j.seppur.2005.06.014

[4] Juang, R.S., Kao, H.C. and Chen, W. (2006) Column Removal of Ni(II) from Synthetic Electroplating Waste Water Using a Strong-Acid Resin. Separation and Purification Technology, 49, 36-42. http://dx.doi.org/10.1016/j.seppur.2005.08.003

[5] Donia, A.M., Atia, A.A. and Elwakeel, K.Z. (2005) Gold(II) Recovery Using Synthetic Resins with Amine, Thio and Amine/Mercaptan Functionalities. Separation and Purification Technology, 42, 111-116. http://dx.doi.org/10.1016/j.seppur.2004.06.009

[6] Chen, C.Y., Chiang, C.L. and Huang, P.C. (2006) Adsorptions of Heavy Metal Ions by a Magnetic Chelating Resin Containing Hydroxy and Iminodiacetate Groups. Separation and Purification Technology, 50, 15-21. http://dx.doi.org/10.1016/j.seppur.2005.11.002

[7] Li, W., Zhao, H., Teasdale, P.R., John, R. and Zhang, S. (2002) Synthesis and Characterization of a PolyacrylamidePolyacrylic Acid Copolymer Hydrogel for Environmental Analysis of $\mathrm{Cu}$ and $\mathrm{Cd}$. Reactive and Functional Polymers, 52, 31-41. http://dx.doi.org/10.1016/S1381-5148(02)00055-X

[8] Kılic, A.G., Malci, S., Elikbıcak, C., Ahiner, N.S. and Salih, B. (2005) Gold Recovery onto Poly(Acrylamide-Allylthiourea) Hydrogels Synthesized by Treating with Gamma Radiation. Analytica Chimica Acta, 547, 18-25. http://dx.doi.org/10.1016/j.aca.2005.03.042

[9] Essawy, H.A. and Ibrahim, H.S. (2004) Synthesis and Characterization of Poly(Vinylpyrrolidone-Co-Methylacrylate) Hydrogel for Removal and Recovery of Heavy Metal Ions from Wastewater. Reactive and Functional Polymers, 61, 421-432. http://dx.doi.org/10.1016/j.reactfunctpolym.2004.08.003

[10] Pekel, N., Savas, H. and Guven, O. (2002) Complex Formation and Adsorption of $\mathrm{V}^{+3}, \mathrm{Cr}^{+3}$ and $\mathrm{Fe}^{3+} \mathrm{Ions}_{\text {with }}$ Poly(N-Vinylimidazole). Colloid and Polymer Science, 280, 46-51. http://dx.doi.org/10.1007/s003960200006

[11] Donia, A.M., Atia, A.A., El-Boraey, H.A. and Mabrouk, D.H. (2006) Adsorption of Ag(I) on Glycidyl Methacrylate/ N,N-Methylene Bis-Acrylamide Chelating Resins with Embedded Iron oXide. Separation and Purification Technology, 48, 281-287. http://dx.doi.org/10.1016/j.seppur.2005.07.034

[12] Febrianto, J., Kosasih, A.N., Sunarso, J., Ju, Y., Indraswati, N. and Ismadji, S. (2009) Equilibrium and Kinetic Studies in Adsorption of Heavy Metals Using Biosorbent: A Summary of Recent Studies. Journal of Hazardous Materials, 162, 616-645. http://dx.doi.org/10.1016/j.jhazmat.2008.06.042

[13] Foo, K.Y. and Hameed, B.H. (2010) Insights into the Modeling of Adsorption Isotherm Systems. Chemical Engineering Journal, 156, 2-10. http://dx.doi.org/10.1016/j.cej.2009.09.013

[14] Rahimi, M. and Vadi, M. (2014) Langmuir, Freundlich and Temkin Adsorption Isotherms of Propranolol on MultiWall Carbon Nanotubes. Journal of Modern Drug Discovery and Drug Delivery Research, 2, 18-20.

[15] Qu, R., Wang, M., Sun, C., Zhang, Y., Ji, C., Chen, H., Meng, Y. and Yin, P. (2008) Chemical Modification of SilicaGel with Hydroxyl- or Amino-Terminated Polyamine for Adsorption of Au(III). Applied Surface Science, 255, 33613370. http://dx.doi.org/10.1016/j.apsusc.2008.09.055

[16] Radi, S., Basbas, N., Tighadouini, S. and Bacquet, M. (2014) New Polysiloxane Surfaces Modified with Ortho-, Metaor Para-Nitrophenyl Receptors for Copper Adsorption. Journal of Surface Engineered Materials and Advanced Technology, 4, 21-28.

[17] Radi, S., Toubi, Y. and Bacquet, M. (2013) Synthesis of Pyridin-3-Yl-Functionalized Silica as a Chelating Sorbent for Solid-Phase Adsorption of $\mathrm{Hg}(\mathrm{II}), \mathrm{Pb}(\mathrm{II}), \mathrm{Zn}(\mathrm{II})$, and $\mathrm{Cd}(\mathrm{II})$ from Water. Research on Chemical Intermediates, 39, 3791-3802. http://dx.doi.org/10.1007/s11164-012-0881-6

[18] Qiu, H., Lv, L., Pan, B., Zhang, Q., Zhang, W. and Zhang, Q. (2009) Critical Review in Adsorption Kinetic Models. Journal of Zhejiang University SCIENCE A, 10, 716-724. http://dx.doi.org/10.1631/jzus.A0820524

[19] He, J., Hong, S., Zhang, L., Gan, F. and Ho, Y. (2010) Equilibrium and Thermodynamic Parameters of Adsorption of Methylene Blue onto Rectorite. Fresenius Environmental Bulletin, 19, 2651-2656.

[20] Sridev, D. and Rajendran, K. (2009) Synthesis and Optical Characteristics of ZnO Nanocrystals. Bulletin of Materials Science, 32, 165-168. http://dx.doi.org/10.1007/s12034-009-0025-9 
[21] Ferrari, L., Kaufmann, J. and Plank, J. (2010) Interaction of Cement Model Systems with Super Plasticizers Investigated by Atomic Force Microscopy, Zeta Potential, and Adsorption Measurements. Journal of Colloid and Interface Science, 347, 15-24.

[22] Foo, K.Y. and Hameed, B.H. (2010) Insights into the Modeling of Adsorption Isotherm Systems. Chemical Engineering Journal, 156, 2-10. http://dx.doi.org/10.1016/j.cej.2009.09.013

[23] Agrawal, A. and Sahu, K. (2009) Kinetics and Isotherm Studies of Cadmium Adsorption on Manganese Nodule Residue. Journal of Hazardous Materials, 137, 915-924. http://dx.doi.org/10.1016/j.jhazmat.2006.03.039

[24] Jodeh, S., Basalat, N., Abu Obaid, A., Bouknana, D., Hammouti, B., Hada, T., Jodeh, W. and Warad, I. (2014) Adsorption of Some Organic Phenolic Compounds Using Activated Carbon from Cypress Products. Journal of Chemical and Pharmaceutical Research, 6, 713-723.

[25] Lin, J. and Wang, L. (2009) Comparison between Linear and Non-Linear Forms of Pseudo-First-Order and Pseudo-Second-Order Adsorption Kinetic Models for the Removal of Methylene Blue by Activated Carbon. Journal of Environmental Science and Engineering, 83, 11-17.

[26] Jodeh, S., Khalaf, O., Abu Obaid, A., Hammouti, B., Hadda, B., Jodeh, W., Haddad, M. and Warad, I. (2014) Adsorption and Kinetics of Abamectin and Imidacloprid in Greenhouse Soil in Palestine. Journal of Materials and Environmental Science, 5, 571-580.

[27] Elmolla, M. and Chaudhuri, M. (2009) Improvement of Biodegradability of Synthetic Amoxicillin Wastewater by Photo-Fenton Process. World Applied Science Journal, 5, 53-58.

[28] Tan, I., Hameed, B. and Ahmad, A. (2007) Equilibrium and Kinetic Studies on Basic Dye Adsorption by Oil Palm Fiber Activated Carbon. Chemical Engineering Journal, 127, 111-119. 